\title{
MENGUKUR MANFAAT EKONOMIS SISTEM APLIKASI MONITORING ATM DENGAN METODE INFORMATION ECONOMICS: STUDI KASUS PT BANK XYZ TBK.
}

\author{
Viany Utami Tjhin'; Hudiarto²; Intan Puspita ${ }^{3}$
}

\begin{abstract}
Research discusses information economics method to measure the economic benefit from information technology application. Research with information economics method is applied on Gasper Vantage, ATM monitoring application system that is used by XYZ Bank Company. The Gasper Vantage is applied to increase the ATM availability and to give a better service to customer. From the research, the Gasper Vantage can be use by XYZ Bank Company and also increasing the company competitive advantage.
\end{abstract}

Keywords: economic, information economics, information technology, Gasper Vantage

\begin{abstract}
ABSTRAK
Penelitian membahas metode information economics untuk mengukur manfaat ekonomis dari penerapan teknologi informasi. Penelitian dengan metode information economics ini diterapkan pada Gasper Vantage, sebuah sistem aplikasi monitoring ATM yang digunakan oleh PT Bank XYZ Tbk. Gasper Vantage ini diterapkan untuk meningkatkan availability ATM dan untuk memberikan pelayanan yang lebih baik kepada nasabah. Dari hasil penelitian, diketahui bahwa penerapan Gasper Vantage bermanfaat bagi PT Bank XYZ Tbk dan turut meningkatkan keunggulan bersaing perusahaan.
\end{abstract}

Kata kunci: ekonomis, information economics, teknologi informasi, Gasper Vantage

\footnotetext{
${ }^{1 \& 2}$ Staf pengajar Fakultas Ekonomi, UBiNus, Jakarta

${ }^{3}$ Mahasiswa Fakultas Ekonomi, UBiNus, Jakarta
} 


\section{PENDAHULUAN}

Seiring dengan meningkatnya persaingan dalam dunia industri, peranan teknologi informasi menjadi semakin penting bagi perusahaan untuk meningkatkan keunggulan bersaing. Hal itu menjadi suatu hal yang diperhatikan oleh pihak manajemen Teknologi Informasi (TI) karena penggunaan teknologi informasi membutuhkan investasi dana yang besar. Investasi yang besar itu umumnya disertai dengan potensi risiko yang besar juga dan dapat menimbulkan kerugian yang besar apabila keputusan yang diambil tidak tepat. Begitu pula terhadap proyek TI yang sudah diterapkan dalam perusahaan. Agar biaya investasi serta biaya berjalan yang dikeluarkan tidak sia-sia, manajemen perlu melakukan evaluasi dengan cara mengukur manfaat ekonomis dari proyek TI tersebut secara berkala.

Pengukuran manfaat ekonomis suatu proyek TI memerlukan metode yang dapat merangkum secara menyeluruh manfaat ekonomis yang ditimbulkan bagi perusahaan. Metode itu adalah metode Information Ecomomics yang diperkenalkan oleh Marylin M. Parker pada tahun 1988. Dengan metode itu, pihak manajemen TI ingin mengetahui berapakah manfaat ekonomis yang ditimbulkan oleh sistem aplikasi monitoring ATM yang digunakan bagi perusahaan.

\section{Hubungan Penggunaan Teknologi Informasi dengan Dampak Ekonomisnya bagi Perusahaan}

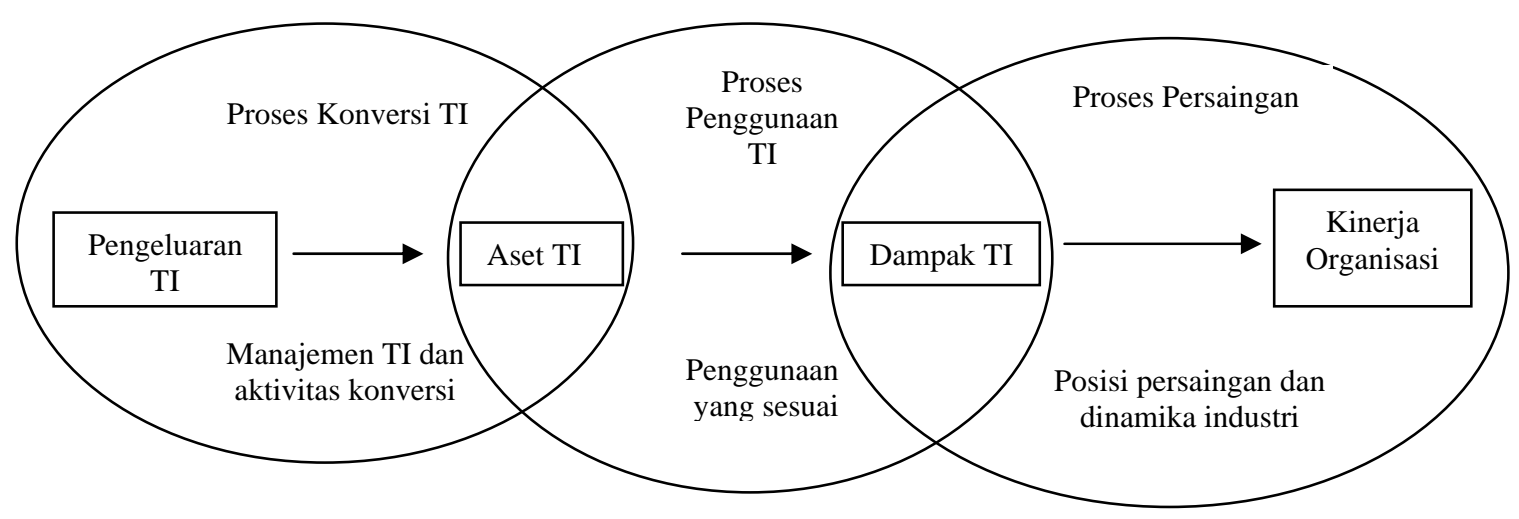

Gambar 1 Skema Proses Penggunaan Teknologi Informasi dan Dampak Ekonomisnya bagi Perusahaan (Devaraj, 2002:45)

Soh dan Markus dalam bukunya How IT creates Business Value: A Process Theory Synthesis (Devaraj, 2002:45) menjelaskan tentang skema proses penggunaan suatu proyek teknologi informasi serta dampaknya bagi perusahaan yang menggunakan. Skema itu terdiri dari 3 lingkaran yang saling berhubungan dan berpotongan satu sama 
lain. Pada lingkaran proses konversi TI, digambarkan bahwa dalam suatu tahapan penggunaan TI pasti dimulai dengan pengeluaran untuk memperoleh proyek TI yang diperlukan. Perolehan itu dapat dilakukan dengan membuat sendiri suatu sistem khusus atau membeli sistem jadi atau bahkan menyewa sistem pada vendor.

Pada lingkaran itu, terjadi proses konversi pengeluaran TI menjadi aset TI. Setelah pengeluaran TI dibelikan asset TI, pada lingkaran tengah aset TI yang dimiliki akan digunakan sesuai fungsinya dalam operasional perusahaan sehingga menimbulkan dampak bagi bisnis perusahaan. Dampak yang diberikan tidak hanya berupa manfaat saja tetapi juga ada risiko yang harus ditanggung oleh perusahaan. Dampak yang dirasakan oleh perusahaan akan berpengaruh pada kinerja perusahaan dalam dunia persaingan. Pada lingkaran proses persaingan, digambarkan penyelarasan dampak TI yang dapat diperoleh dari aset TI yang dimiliki dengan kebutuhan perusahaan dalam persaingan bisnis industri. Oleh karena itu, bila dilihat secara keseluruhan maka skema itu memiliki pengertian bahwa pengeluaran yang dilakukan untuk implementasi aset TI akan membawa suatu dampak ekonomis bagi perusahaan yang menggunakannya.

\section{Metode Information Economics}

Metode ini dirancang dan dikembangkan oleh Marylin M. Parker pada tahun 1985. Menurut Parker (1988:5), Information Economics merupakan sekumpulan teknik penghitungan untuk menghitung manfaat dan biaya dari suatu proyek teknologi informasi. Information economics dikembangkan karena adanya kebutuhan dari pihak perusahaan untuk mengetahui bagaimana dampak ekonomis pengeluaran dana investasi untuk proyek TI terhadap bisnis perusahaan. Metode information economics mengisi kekosongan yang ada pada TCBA dengan cara menghitung manfaat yang sifatnya kualitatif ke dalam bentuk rupiah melalui perhitungan value linking, value acceleration, value restructuring, dan innovation valuation. Dalam metode information economics ini terdapat beberapa istilah yang sering muncul, seperti biaya (cost), manfaat (benefit), nilai (value), domain bisnis, dan domain teknologi.

\section{Biaya (Cost)}

Biaya (cost) merupakan suatu pengukuran atas jumlah sumber daya yang dibutuhkan untuk memperoleh sebuah produk (Parker, 1988:90). Biaya dinyatakan dalam ukuran mata uang (misalnya, rupiah). Dalam information economics terdapat dua jenis biaya, yaitu biaya pengembangan (development cost) dan biaya berjalan (ongoing cost). Biaya pemeliharaan (maintenance) termasuk dalam biaya berjalan.

\section{Manfaat (Benefit)}

Menurut Remenyi (1995:40), manfaat (benefit) teknologi informasi merupakan suatu keuntungan atau kebaikan yang diperoleh dari teknologi informasi terhadap suatu perusahaan yang bersedia untuk membayar atas penggunaan teknologi informasi. 
Terdapat empat kategori manfaat menurut Remenyi (1995:42) dalam IT benefit matrix, sebagai berikut.

1. Tangible Measurable merupakan manfaat yang membawa dampak langsung terhadap profitabilitas perusahaan dan dampak tersebut dapat diukur secara objektif. Contohnya adalah pengurangan staf dan aset serta peningkatan penjualan.

2. Tangible Unmeasurable merupakan manfaat yang membawa dampak langsung terhadap profitabilitas perusahaan tetapi sulit untuk langsung diukur. Contohnya adalah informasi yang lebih baik, perbaikan keamanan, dan risiko yang lebih rendah.

3. Intangible Measurable merupakan manfaat yang dapat diukur tetapi dampaknya tidak secara langsung mempengaruhi profitabilitas perusahaan. Contohnya adalah infomasi yang lebih cepat dan tanggapan yang positif dari staf.

4. Intangible Unmeasurable merupakan manfaat yang sulit diukur dan dampaknya tidak secara langsung mempengaruhi profitabilitas perusahaan. Contohnya adalah reaksi positif pasar pada perusahaan dan persepsi positif dari calon konsumen dan calon karyawan terhadap perusahaan.

\section{Nilai}

Nilai didasarkan pada manfaat yang ditunjukkan dari kinerja bisnis masa sekarang dan masa akan datang (Parker, 1988:64). Manfaat yang akan meningkatkan keunggulan kompetitif perusahaan merupakan nilai ketika perusahaan (manajemen) bersedia melakukan investasi untuk mencapainya. Nilai suatu manfaat akan bernilai positif dalam perhitungan sedangkan risiko akan bernilai negatif. Pada metode information economics terdapat istilah value linking, value acceleration, value restructuring, dan innovation valuation.

1. Value linking digunakan untuk mengevaluasi secara finansial dampak yang timbul dari pengembangan kinerja suatu fungsi dan konsekuensi hasil yang dirasakan oleh fungsi yang terkait.

2. Value acceleration atau nilai percepatan digunakan untuk mengevaluasi secara finansial setiap perubahan yang cepat akan manfaat maupun biaya dari setiap departemen yang berhubungan dan tergantung dengan waktu.

3. Value restructuring mengukur nilai yang berhubungan dengan restrukturisasi suatu pekerjaan ataupun fungsi departemen. Value restructuring mengukur nilai peningkatan produktivitas akibat perubahan yang dilakukan organisasi.

4. Innovation valuation dilakukan untuk menilai terciptanya fungsi baru dalam domain bisnis organisasi.

\section{Domain}

Istilah "domain" digunakan untuk mengarakteristikkan kedua kegiatan yang berbeda, yaitu domain bisnis adalah pengguna teknologi (user) dan domain teknologi adalah penyedia teknologi. 
Metode information economics menggunakan analisis dua domain dalam perhitungannya. Analisis dua domain itu akan menghasilkan nilai proyek TI yang bersifat unik pada domain bisnis dan teknologi. Dari kedua domain itu dikumpulkan bobot korporasi Bank XYZ terhadap proyek TI dan nilai proyek TI yang akan diukur. Angka pada bobot korporasi menunjukkan preferensi (kecondongan) Bank XYZ dalam memilih proyek TI yang diperlukan. Nilai proyek TI menunjukkan manfaat dan risiko proyek TI yang diukur terhadap preferensi Bank XYZ.

Tabel 1 Faktor unik pada Domain Bisnis dan Teknologi dalam metode Information Economics (Parker, 1996:308-327)

\begin{tabular}{lll}
\hline & Faktor Domain Bisnis & Faktor Domain Teknologi \\
\hline Financial Values & Business-based Financial & \\
Strategic Values & Salue & \\
& Strategic Match & \\
& Competitive Advantage & \\
& Competitive Response & \\
& Management Information for & \\
& CSF & \\
Stakeholder Values & Service and Quality & \\
& Agility, Learning, and & \\
& Empowerment & \\
& Cycle Time & \\
& Mass Customization & \\
Cometitive Strategy Risk & Business Strategy Risk & \\
Organization Risk and & Business Organization Risk & I/T Strategy Risk \\
Uncertainty & & I/T definition Uncertainty \\
& & Technology and \\
& & Implementation Risk \\
& & I/T Service Delivery Risk \\
\hline
\end{tabular}

\section{Tahapan Analisis Information Economics}

Tahap analisis Information Economics sebagai berikut: Analisis manfaat tangible measurable menggunakan Cost-Benefit Analysis (CBA) tradisional yang akan menghasilkan manfaat ekonomis netto, $\mathrm{ROI}_{1}$, dan skor untuk dampak ekonomis yang pertama. Selanjutnya, berdasarkan jenis manfaat yang diperoleh, dilakukan kuantifikasi value linking dan value acceleration. Setelah itu, dijumlahkan dengan $\mathrm{ROI}_{1}$ untuk memperoleh $\mathrm{ROI}_{2}$ dan skor dampak ekonomis yang kedua. Value restructuring dikaitkan dengan manfaat yang ada dan hasilnya akan dijumlahkan dengan $\mathrm{ROI}_{2}$ untuk memperoleh $\mathrm{ROI}_{3}$ dan skor dampak ekonomis yang ketiga. Setelah itu, manfaat yang diperoleh dari innovation valuation akan dijumlahkan dengan $\mathrm{ROI}_{3}$ menghasilkan $\mathrm{ROI}_{4}$ dan skor dampak ekonomis yang keempat. Dari domain bisnis dan teknologi, diperoleh bobot korporasi dan nilai proyek TI yang diukur berdasarkan faktor unik yang ada. 


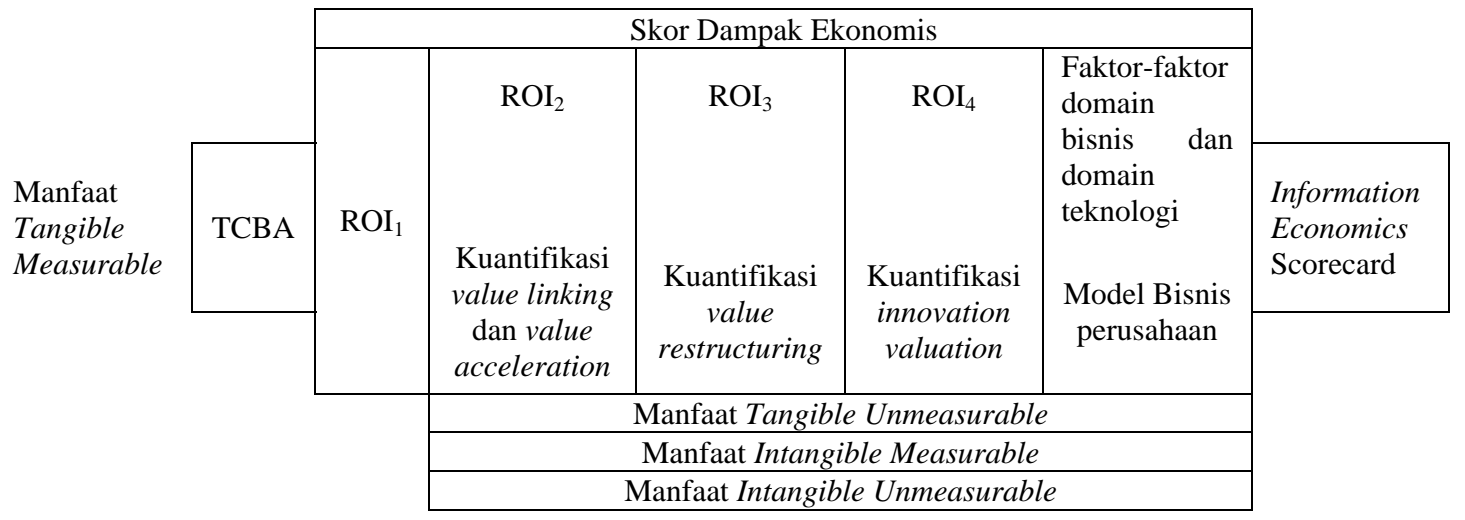

Gambar 2 Tahapan Analisis Information Economics

(Sumber: Fendy, 2002:30)

Untuk memperoleh score information economics, hasil perhitungan ROI (dalam bentuk skor) serta bobot korporasi perusahaan dan nilai proyek dimasukkan ke dalam information economics scorecard. Baris faktor pada Information Economics Scorecard diisi dengan bobot korporasi sedangkan baris domain bisnis dan domain teknologi diisi dengan nilai proyek TI yang diukur. Keduanya dikalikan dan dijumlahkan untuk memperoleh skor information economics yang menggambarkan manfaat ekonomis yang diberikan oleh proyek TI yang diukur kepada perusahaan.

\section{Objek Penelitian}

Sistem aplikasi monitoring ATM yang digunakan adalah Gasper Vantage versi 5.2 (selanjutnya disebut Gasper Vantage) yang diproduksi oleh NCR dari Gasper Corporation. Dengan penggunaan Gasper Vantage dalam memonitor status mesin ATM yang ada, diharapkan mesin ATM dapat selalu digunakan dan bebas dari masalah (error) sehingga dapat selalu digunakan oleh nasabah. Namun demikian, sangatlah sulit untuk menghindari error $100 \%$. Oleh karena itu, untuk memperkecil error yang terjadi, Gasper Vantage akan melaporkan langsung (secara realtime) mesin ATM mana yang mengalami masalah. Kondisi yang demikian akan ditangkap (capture) dan dilaporkan oleh Gasper Vantage ke monitor aplikasi sehingga dapat dilakukan error handling (penyelesaian masalah) dan error preventive (pencegahan error) secepatnya. Gasper Vantage menggabungkan fungsi di bawah ini.

1. Online monitoring (pemantauan online).

2. Data collection (pengumpulan data).

3. Incident tracking (penjelajahan masalah).

4. Rules - based commands (memberikan perintah sesuai prosedur).

5. Database File Server for LAN and WAN access to reporting capabilities (penyediaan file database server untuk akses LAN dan WAN untuk pembuatan laporan). 
6. Automated dispatching via voice response, pager, and electronic method (pengiriman pesan secara otomatis secara elektronik. Dalam hal ini metode yang digunakan adalah Short Messages Sending/SMS).

\section{PEMBAHASAN}

\section{Manfaat Gasper Vantage}

Dengan mengacu pada manfaat yang diperoleh dari fungsi ATM, berikut ini merupakan manfaat yang diberikan oleh Gasper Vantage. Adapun identifikasi manfaat yang dilakukan didasarkan pada teori IT Benefit Matrix dan manfaat dikategorikan menjadi 4 bagian, yaitu tangible measurable, tangible unmeasurable, intangible measurable, dan intangible unmeasurable. Manfaat Gasper Vantage dapat dilihat pada Tabel 2.

Tabel 2 Identifikasi Manfaat Gasper Vantage

\begin{tabular}{ll}
\multicolumn{1}{c}{ Kategori Manfaat } & \multicolumn{1}{c}{ Manfaat Gasper Vantage } \\
\hline Tangible Measurable & 1. Penghematan Biaya Telepon \\
& 2. Pengurangan Tenaga Kerja \\
Tangible Unmeasurable & 1. Pengelolaan data yang lebih baik \\
& 2. Informasi yang lebih cepat \\
Intangible Measurable & 3. Proactive Monitoring System \\
& 1. Peningkatan availability ATM \\
Intangible Unmeasurable & 2. Efisiensi waktu kerja ATM \\
\hline
\end{tabular}

Dari manfaat itu, dilakukan kuantifikasi satu-persatu. Berdasarkan contoh yang diberikan dalam teori Parker, perhitungan finansial dilakukan untuk periode 5 tahun. Dalam perhitungan finansial, digunakan metode TCBA dengan beberapa komponen perhitungan, seperti berikut ini.

1. Development Cost sebesar Rp1,244,850,000.00.

2. Ongoing Cost sebesar Rp992,190,733.89 untuk periode 5 tahun.

3. Manfaat langsung sebesar Rp2,153,879,280.00 untuk periode 5 tahun. (dalam economic impact worksheet ditulis sebagai Operating Cost Reduction) 
Mengukur Manfa at Ekonomis... (Viany Uta mi Tjhin; Hudiarto; Intan Puspita) 
Dengan metode TCBA, perhitungan ROI hanya didasarkan pada ke-3 komponen tersebut. Dari hasil perhitungan itu diperoleh nilai ROI sebesar $18.66 \%$ dan berada pada skor 1. Namun, dengan metode information economics, ada penambahan perhitungan value linking, value acceleration, value restructuring, dan innovation valuation yang akan melengkapi kekosongan perhitungan pada TCBA. Pada penelitian ini, hanya teridentifikasi value linking dan value acceleration. Value linking yang diperoleh adalah peningkatan availability ATM meningkatkan pendapatan fee bagian penjualan senilai Rp2,277,176,548.05 untuk periode 5 tahun. Value acceleration yang diperoleh adalah percepatan proses kerja bagian ATM Support (sebutan untuk technical support ATM) sehingga perusahaan dapat merealokasi sebagian tenaga kerja yang ada ke divisi lain yang membutuhkan. Value acceleration ini memberi manfaat sebesar Rp 367,567,200.00 untuk periode 5 tahun. Hasil kuantifikasi value linking dan value acceleration ini akan ditambahkan dalam economic impact worksheet sebagai Net Economic Benefit. Angka itu akan dihitung kembali untuk memperoleh nilai ROI yang baru.

Tabel 5 Total Nilai Net Economic Benefit (dalam ribuan Rp)

\begin{tabular}{lcccccc}
\hline Keterangan & 2004 & 2005 & 2006 & 2007 & 2008 & Total \\
\hline Value Linking & $122,400,000.00$ & $428,400,000.00$ & $494,802,000.00$ & $571,496,310.00$ & $660,078,238.05$ & $2,277,176,548.05$ \\
Value & & & & & & \\
Acceleration & & $79,200,000.00$ & $87,120,000.00$ & $95,832,000.00$ & $105,415,200.00$ & $367,567,200.00$ \\
\hline Total & $122,400,000.00$ & $507,600,000.00$ & $581,922,000.00$ & $667,328,310.00$ & $765,493,438.05$ & $2,644,743,748.05$ \\
\hline
\end{tabular}

(Sumber: data diolah. Data per 2004) 
Mengukur Manfa at Ekonomis... (Viany Uta mi Tjhin; Hudiarto; Intan Puspita) 
Dari perhitungan dampak ekonomis yang kedua (setelah ada penambahan value linking dan value acceleration), diperoleh nilai ROI yang baru sebesar 61.15\%. Hal itu menunjukkan bahwa manfaat Gasper Vantage tidak hanya dirasakan oleh departemen ATM saja tetapi juga berdampak pada departemen pejualan. Skor ROI yang baru ini tetap bernilai 1. Tahap berikutnya adalah mengumpulkan bobot korporasi dan nilai proyek Gasper Vantage. Angka itu diperoleh dengan bantuan kuesioner.

Tabel 6 Bobot Korporat Bank Lippo untuk Proyek TI

\begin{tabular}{|c|c|c|}
\hline Domain Bisnis & Faktor-Faktor & Bobot \\
\hline Financial Value & ROI & +4 \\
\hline \multirow[t]{4}{*}{ Strategic value } & Strategic Match & +4 \\
\hline & Competitive Advantage & +5 \\
\hline & Competitive Response & +4 \\
\hline & Management Information for Critical Success Factors & +5 \\
\hline \multirow[t]{5}{*}{ Stakeholder Values } & Service and Quality & +4 \\
\hline & Environmental Quality & +4 \\
\hline & Agility Learning and Empowerment & +4 \\
\hline & Cycle-Time & +5 \\
\hline & Mass Customization & +4 \\
\hline Competitive Strategy Risk & Business Strategy Risk & -3 \\
\hline $\begin{array}{l}\text { Organizational Strategy } \\
\text { Risks and Uncertainties }\end{array}$ & Business Organization Risk & -3 \\
\hline Domain Teknologi & Faktor-Faktor & Bobot \\
\hline Stakeholder Values & Strategic I/T Architecture & +4 \\
\hline Competitive Strategy Risk & I/T Strategy Risk & -3 \\
\hline \multirow{3}{*}{$\begin{array}{l}\text { Organizational Strategy and } \\
\text { Uncertainties }\end{array}$} & I/T Definitional Uncertainty & -3 \\
\hline & I/T Technical and Implementation Risk & -4 \\
\hline & I/T Services Delivery Risk & -2 \\
\hline \multicolumn{2}{|c|}{ Total Bobot Korporat untuk Manfaat } & +47 \\
\hline \multicolumn{2}{|c|}{ Total Bobot Korporat untuk Risiko } & -18 \\
\hline
\end{tabular}

(Sumber: Manajer Branch and ATM Support Departement Bank XYZ Kantor Pusat. Data per November 2004)

Tabel 7 Nilai Proyek Gasper Vantage

\begin{tabular}{crr}
\hline Domain Bisnis & Faktor-faktor & $\begin{array}{c}\text { Nilai Proyek } \\
\text { Gasper Vantage }\end{array}$ \\
\hline Financial Value & ROI & 1 \\
Strategic Values & Strategic Match & 4 \\
& Competitive Advantage & 4 \\
& Competitive Response & 5 \\
& Management Information for Critical & 4
\end{tabular}


Tabel 7 Nilai Proyek Gasper Vantage (lanjutan)

\begin{tabular}{rrr}
\hline Stakeholder Values & Service and Quality & 4 \\
& Environmental Quality & 5 \\
& Agility Learning and Empowerment & 5 \\
& Cycle-Time & 4 \\
Competitive Strategy Risk & Mass Customization & 3 \\
Organizational Strategy & Business Strategy Risk & 1 \\
Risks and Uncertainties & Business Organization Risk & 0 \\
\hline Domain Teknologi & & \\
& Faktor-faktor & Nilai Proyek Gasper \\
Stakeholder Value & Vantage \\
\hline Competitive Strategy Risk & I/T Strategy Risk & 4 \\
Organizational Strategy and & I/T Definitional Uncertainty & 0 \\
Uncertainties & I/T Technical and Implementation Risk & 2 \\
& I/T Services Delivery Risk & 1.6 \\
\hline
\end{tabular}

(Sumber: Manajer Branch and ATM Support Departement Bank XYZ Kantor Pusat. Data per November 2004)

Angka itu kemudian dimasukkan ke dalam information economics scorecard untuk mendapatkan skor information economics. Untuk Gasper Vantage ini, skor IE yang diperoleh adalah 167.6. Makna angka 167.6 itu dapat dilihat pada tabel penetapan manfaat skor IE. Tabel manfaat itu dibuat berdasarkan rentang yang terbentuk dari skor minimum dan skor maksimum Gasper Vantage kemudian dibagi ke dalam 5 kelas.

1. Skor Information Economics minimum Gasper Vantage:

$=[47 \times 0]+[-18 \times 5]$

$=-90$

2. Skor Information Economics maksimum Gasper Vantage:

$=[47 \times 5]+[-18 x 0]$

$=235$

Tabel 8 Penetapan Manfaat Skor IE

\begin{tabular}{ccc}
\hline Skor IE & Skala & Keterangan \\
\hline $235-170$ & 5 & Bermanfaat sekali \\
$169-105$ & 4 & Bermanfaat \\
$104-40$ & 3 & Cukup Bermanfaat \\
$39-(-25)$ & 2 & Kurang Bermanfaat \\
$24-(-90)$ & 1 & Kurang Bermanfaat Sekali \\
\hline
\end{tabular}

Dengan mengacu pada keterangan yang ada pada tabel penetapan manfaat, didapatkan bahwa skor 167.6 menunjukkan bahwa Gasper Vantage secara keseluruhan bermanfaat bagi perusahaan.

Mengukur Manfa at Ekonomis... (Viany Uta mi Tjhin; Hudia rto; Intan Puspita) 


\section{PENUTUP}

Sesuai dengan pembahasan, dapat disimpulkan beberapa hal sebagai berikut.

1. Manfaat ekonomis langsung yang diperoleh Bank XYZ dari penerapan Gasper Vantage adalah penghematan biaya telepon dan pengurangan tenaga kerja dengan total penghematan sebesar Rp2,153,879,280.00 untuk periode 5 tahun. Dari manfaat langsung itu diperoleh ROI sebesar 18.66\%. Angka itu berarti tingkat pengembalian investasi Gasper Vantage per tahun adalah 18.66\% dari biaya investasi.

2. Manfaat ekonomis naik dari Rp2,153,879,280.00 menjadi Rp4,798,623,028.05 setelah dilakukan kuantifikasi value linking dan value acceleration sebesar Rp2,644,743,748.05. Kenaikan itu berakibat juga pada peningkatan ROI dari dampak ekonomis pertama sebesar $18.66 \%$ menjadi $61.15 \%$ pada dampak ekonomis yang kedua.

3. Metode information economics memberikan pandangan yang lebih luas kepada manajemen dalam mengukur manfaat ekonomis Gasper Vantage karena dalam metode ini tidak hanya memperhatikan dari segi keuangan saja, tetapi juga dari segi domain bisnis dan teknologi. Pelibatan faktor domain bisnis dan teknologi dalam perhitungan information economics ternyata memberikan hasil skor information economics yang tinggi, yaitu 4 dari nilai maksimum 5.

4. Secara keseluruhan, pengukuran manfaat ekonomis Gasper Vantage sebagai sistem aplikasi monitoring ATM dengan metode information economics menghasilkan informasi bahwa Gasper Vantage bermanfaat bagi Bank XYZ.

\section{DAFTAR PUSTAKA}

Devaraj, S. and R. Kohli. 2002. The IT Payoff: Measuring the Business Value of Information Technology Investemnts. New Jersey: Prentice Hall.

Parker, M.M. 1996. Strategic Transformation and Information Technology: Paradigm for Performing While Transforming. New Jersey: Prentice Hall.

Parker, M. M., J. Benson Robert, and H. E. Trainor. 1988. Information Economics: Linking Business performance to Information Technology. New Jersey: Prentice Hall.

Remenyi, D., M. Arthur, and T. Alan. 1995. Effective Measurement and Management of IT Costs and Benefits. Oxford: Butterworth Heinemann.

Walker, Gary. 2001. IT Problem Management. New Jersey: Prentice Hall.

Ward, J. and Joe Peppard. 2002. Strategic Planning for Information System. Chichester: Baffins Lane.

Mengukur Manfa at Ekonomis... (Viany Uta mi Tjhin; Hudia rto; Intan Pusp ita) 